https://artnodes.uoc.edu

\title{
Divergent Theoretical Trajectories in Game Studies: A Bibliographical Review
}

\author{
Rosa Núñez-Pacheco \\ Universidad Nacional de San Agustín de Arequipa \\ Phillip Penix-Tadsen \\ University of Delaware
}

Date of submission: February 2021

Accepted in: April 2021

Published in: July 2021

\section{Recommended citation}

Núñez-Pacheco, Rosa; Penix-Tadsen, Phillip. 2021. «Divergent Theoretical Trajectories in Game Studies: A Bibliographical Review». Artnodes, no. 28. UOC. [Accessed: dd/mm/yy]. http:// doi.org/10.7238/a.v0i28.380176

The texts published in this journal are - unless otherwise indicated - covered by the Creative Commons Spain Attribution 4.0 International license. The full text of the license can be consulted here: http://creativecommons.org/licenses/by/4.0/

\begin{abstract}
Video games have become important objects of study for different academic disciplines. From the birth of the medium in the mid-twentieth century to the present, video games have offered new and creative ways of approaching reality and fiction, and not only serve as entertainment, but also have significant cultural, social, and technological implications. The formal study of this medium is the purview of the field of game studies, which brings together the contributions of various disciplines. This paper presents a bibliographical review of several theoretical trajectories in game studies, reflecting on the relevance of early debates on narratology and ludology, and examining the ways these initial divisions of the field have branched beyond that debate. Over the past several years, the narratological line of critique has established links with other theories such as cognitivism, the theory of fictional worlds and the contributions of
\end{abstract}




\section{artnodes}

https://artnodes.uoc.edu

Divergent Theoretical Trajectories in Game Studies: A Bibliographical Review

unnatural narratology to the analysis of new technologies; ludology, for its part, has grown through its adaptations to postcolonial and decolonial theories in cultural studies, as well as through its connections to critical race and gender studies. We conclude that as game studies has evolved as a discipline, its initial theoretical debates have undergone profound transformations that have brought depth to the analysis of games' meaning and diversified to the tools and techniques we have for analysing games as digital and cultural artefacts.

\section{Keywords}

Video games, Narratology, Ludology, Ludofiction, Game Studies

\section{Trayectorias teóricas divergentes en los Game Studies: una revisión bibliográfica}

\section{Resumen}

Los videojuegos se han convertido en importantes objetos de estudio para distintas disciplinas académicas. Desde el nacimiento del medio a mediados del siglo xx hasta la actualidad, los videojuegos han planteado novedosas y creativas formas de acercarnos a la realidad y la ficción, no solo con una finalidad de divertimento, sino también con implicancias culturales, sociales y tecnológicas. Su estudio formal pertenece al ámbito de los game studies, que reúne los aportes de varias disciplinas. En este artículo se hace una revisión bibliográfica de varias trayectorias teóricas de los game studies, reflexionando sobre la relevancia de los debates tempranos sobre la narratología y la ludología, y examinando las maneras en que estas divisiones iniciales del campo se han expandido más allá de ese debate. Durante los últimos años, la trayectoria crítica de la narratología ha establecido vínculos con otras teorías como la de los mundos ficcionales, el cognitivismo y los aportes de la narratología antinatural para aproximarse a las nuevas tecnologías; la ludología, por su parte, ha crecido mediante sus adaptaciones a las teorías poscoloniales y decoloniales en los estudios culturales, como también por sus conexiones con los estudios críticos de raza y género. Se concluye que, mientras los game studies han evolucionado como disciplina, sus debates teóricos iniciales han experimentado profundas transformaciones que han aumentado la profundidad de los análisis del significado de los juegos, y que también han diversificado las herramientas y técnicas que tenemos para analizar los videojuegos como artefactos digitales y culturales.

\section{Palabras clave}

videojuegos, narratología, Iudología, Iudoficción, Game Studies

\section{Introduction}

In the video game Detroit: Become Human (Quantic Dream 2018), the term divergent is applied to machines produced by the CyberLife corporation that have become a menace to human society because their artificial and emotional intelligence has become so advanced as to make it difficult to distinguish the limits between the human and the cybernetic. In a similar manner, we will use the term "divergent" to refer to the theories that gave rise to the foundational years of game studies as an academic discipline, and the ways in which those initial theories diverged from — and converged with —other theoretical trajectories, blurring the lines established in early debates between narratology and ludology.

The 21st century has been decisive for the discipline of game studies, as a series of important events have taken place that have fostered its development, including the establishment of the journals
Game Studies in 2001 and Games and Culture in 2006, and the formation of the Digital Games Research Association (DiGRA) in 2003 (Mäyrä and Sotamaa 2017). From the start, game studies has been an interdisciplinary field, drawing on theories and methodologies of other fields; however, there has also been a demand for the establishment of a discipline unique unto itself (Mäyrä 2006). In addition to its interdisciplinary nature, game studies has come about as an intercultural field of research as well (Aarseth 2004, 2019). This article presents a bibliographical review of several theoretical trajectories in game studies, reflecting on the relevance of early debates on narratology and ludology, and examining the ways these initial divisions of the field have branched beyond that debate.

Specifically, this article will show how, over the past several years, the narratological line of critique has established links with other theories such as cognitivism, the theory of fictional worlds and the contributions of unnatural narratology to the analysis of 


\section{artnodes}

https://artnodes.uoc.edu

new technologies. At the same time, ludology has grown through its adaptations to postcolonial and decolonial theories in cultural studies, as well as through its connections to critical race and gender studies. And moreover, these two theoretical paradigms have come to overlap at an ever increasing array of intersections (Galloway 2006). We conclude that as game studies has evolved as a discipline, its initial theoretical debates have undergone profound transformations that have brought depth to the analysis of games' meaning and diversified to the tools and techniques we have for analysing games as digital and cultural artefacts.

\section{New Narratologies and Ludofictional Worlds}

For many years, the study of narrative was almost exclusively the domain of literary theory, particularly narratology. This discipline based on the study of stories was given its name by Todorov in his 1969 work Grammar of the Decameron, but its precursors were Vladimir Propp and the Russian formalists in the early decades of the 20th century. What is known as formalist or classical narratology had reached its peak by the 1980s. Later came other scholars such as Monika Fludernik (1996), who established novel proposals regarding what she referred to as 'natural narratology'.

In this way, classical narratology gradually began to disintegrate and give rise to other "post-classical narratologies", to use the term coined by David Herman (1997), now within a post-structural theoretical framework. This dissemination allowed it to connect with other disciplines including cognitive science, feminist studies, postcolonialism and psychoanalysis; this in turn gave rise to new approaches like cognitive narratology, postcolonial narratology and comparative narratology. However, perhaps the most notable connection established was with other narrative media, primarily film at first, and later with other digital media spawned through technological development, like video games. Theorists like Culler (2018) foresee a rebirth in narratology through its connection with the cognitive sciences through the development of "unnatural narratology".

It was precisely the complexity of the new narrative forms that emerged as a result of developing technologies, such as video games, that drove narratologists' interest in these new forms of storytelling. And there was indeed a longstanding debate over whether video games were narratives, or whether they were strictly ludic in nature (Planells 2013, 153). Frasca (2003, further discussed below) came to deny the existence of the debate between narratology and ludology, as from his perspective these two approaches were complimentary ways of approaching the study and analysis of video games. In some ways, Koenitz (2018), in making an ontological map of the foundational canon of interactive narrative forms, corroborates Frasca's perspective, making the opposition between narratology and ludology seem perhaps to have been incorrectly labelled. Finally, Aarseth (2012) concludes that " games is the wrong term
Divergent Theoretical Trajectories in Game Studies: A Bibliographical Review

for ludonarrative software, and that narrative theory, while necessary is not sufficient to understand these new forms." (p. 133).

Over time, the narratological perspective has come to take on further nuances thanks to the contributions of other disciplines that also took an interest in these cultural artefacts. Such is the case with those narratological currents that incorporate other theoretical models such as the theory of possible worlds and foci that have arisen in the cognitive sciences, as seen in the work of Marie-Laure Ryan (2019, 2016).

Some of the most outstanding contributions of the theories of fictional worlds to the analysis of video games come from the work of Lubomir Doležel (2019), who drew on the theoretical trajectory of Thomas Pavel. While Doležel did not directly engage with video games in the way that he did with literary texts, his narrative semantics can be applied to the world of video games. Juul (2005) used Pavel's possible world theory to explain his theory about fictional worlds, and Planells (2017) laid out a model based on the theory of fictional worlds.

Doležel (2019) considers the theory of fictional worlds "as a sign of the emergence of post-poststructuralism" (48), distancing his perspective from other theoretical currents, including some of those connected to post-classical narratology. The author turns to a series of dichotomies that function as nodes for the construction of the branches on his tree. In the fifth node, Total Worlds or Small Worlds, he conceives of fictional worlds "as small structured worlds consisting of a finite number of possible particulars: persons, events, actions, place, and so on" (57).

The Doleželian concept of small worlds is analogous to the notion of storyworlds as defined by Herman, as "global mental representations enabling interpreters to frame inferences about situations, characters, and occurrences either explicitly mentioned or implied by a narrative text or discourse" (cited in Ryan 2019,63). Storyworlds can be reconstructed by the reader-viewer while looking at the screen and/or playing; and they are made up of "states (the properties of the fictional world), events (changes in the state) and actions (the actions undertaken by the characters). These pillars are interrelated, and the relationships among them are what drives the story" (Fernández-Vara 2016, 34).

Along a similar line of thinking we find the work of Ryan, whose contributions have been key to the development of theories of fiction linked to narratology and cognitivism. Ryan (2016) analysed the topic of transmedia narrative and its relationship with transmedia narratology. In one study she contrasts three types of discourse: industry discourse, fan discourse, and the discourse of narratology. In one of her recent publications, Ryan (2019) examines the relationship between the theory of possible worlds and the idea of storyworlds. Summarising her proposal, we can see that she focuses on three types of relationship between texts and narrative worlds: a) a narrative text can portray various ontologically distinct worlds; b) a text can depict a unified world that incorporates different stories; and c) several texts can contribute to the construction of the same world, as in the case of transfictionality. It is important to 


\section{artnodes}

https://artnodes.uoc.edu

note that, according to Ryan, this notion of the storyworld is ideal for the development of immersion and the practice of transfictionality.

Alice Bell (2016) is another scholar whose work is in line with that of Ryan and Herman, but who has more directly applied the theory of possible worlds to the study of digital media. Bell takes up the concept of metalepsis, originally laid out by Genette, through which an element of the extradiegetic world is incorporated into the diegetic world, or vice versa. Her interests are focused on transmedial narrative elements like digital fictions, tabletop role-playing games and video games. Bell further expands upon various subtypes of metalepsis including Metaleptic Webcams, Metaleptic Hyperlinks and Metaleptic Breath, which utilises biotechnology. All of these forms of metalepsis combine to constitute unnatural narratology.

Finally, Lisbeth Klastrup and Susana Tosca have proposed the term "transmedial worlds," defined as "abstract content systems from which a repertoire of fictional stories and characters can be actualised or derived across a variety of media forms." $(2004,409)$. These media may be books, video games, cards, films, etc. Unlike theorists such as Henry Jenkins and Marie-Laure Ryan, who opt for the term "transmedia storytelling," Klastrup and Tosca argue that the concept of transmedial worlds allows us to analyse both developers and users, independent of the platform used to create a work of fiction. In these transmedial worlds, video games offer some of the greatest possibilities for interaction and immersion, and have spurred the development of new narratological paradigms for approaching ludofictional works like those described above.

\section{From Formalist Ludology to Cultural Ludology}

Ludology, like narratology, has gone through successive waves of popularity and infamy in game studies discourse. Frasca originally framed the case for ludology by positing that video games must be studied as games, that is as products of a unique medium with its own ways of communicating meaning (1999). Critiques of this perspective arose quickly, with some accusing Frasca and his fellow ludologists of a sort of formalist-style essentialism for their focus on "the game itself", (Jones 2008,5 ) at the expense of other important factors such as the cultural environment in which the games are produced and consumed, the role of player identity and the social dynamics of gaming communities.

At its worst, a formalist or orthodox ludology could be seen as an overly simplistic, technocentric approach to understanding games as software more than as cultural products. While ludology aimed to turn our critical gaze away from the "screen essentialism" that has frequently characterised game analysis (Montfort 2004), it may have supplanted one essentialist approach with another. Removed from the contexts of their development and circulation, games can be understood with precision from the perspective of mechanics and rules, but at the expense of understanding how games affect the people who design, manufacture, buy, sell and play them.
Divergent Theoretical Trajectories in Game Studies: A Bibliographical Review

Sometimes the explanations that sound the best at first turn out to be too good to be true. Johan Huizinga's concept of the "magic circle"-a separate, sacred space in which gaming takes place, distinct from "real life"-has proven too reductive to encompass the blending of real and virtual worlds that takes place when players of video games communicate with one another about the game, research tricky parts of games on websites, watch other players as spectators rather than playing themselves or pause their games to get a snack.

As Gordon Calleja emphatically argues: "Reality cannot be bracketed by closed or open circles, even if we could argue that such bracketing is logically possible" (48). Likewise, Miguel Sicart proposes a notion of play that runs counter to Huizinga: "I am not going to oppose play to reality, to work, to ritual or sports because it exists in all of them." (3) Thus, just as with a hermetic conception of the golden circle, the idea of a strict ludology capable of unlocking games' meaning through adherence to the internal meaning-making mechanisms of their software and hardware may have been an unrealistic dream. Games are not separate from real life, nor can they be studied in complete isolation.

This, in part, is why approaches to game studies have flourished and diversified in recent times. As authors and critics explore different perspectives with regard to games and game cultures, new voices and points of focus come to the fore. Patrick Jagoda cites three primary methodological approaches to 21st-century videogame criticism: game aesthetics and form; video game culture and history; and practical design (213-215). And yet even within this everdiversifying framework, formalist strands of ludology are expanding and multiplying, breaking out of the imagined mould of "orthodox" ludology to examine games with specific attention to their platforms and mechanics, but also as products of human culture.

Such is the case with some of the strongest work in the field of critical code studies, which Mark C. Marino (2006) defines as "an approach that applies critical hermeneutics to the interpretation of computer code, program architecture, and documentation within a socio-historical context." Likewise, the hardware-centred approach taken by practitioners of platform studies can reveal the myriad ways the obstacles and affordances of different technological platforms, hardware specifications, game design engines and software impact the ways games are developed. In their introduction to their "Platform Studies" series published with MIT Press, Nick Montfort and lan Bogost explain that their approach is based on "the investigation of underlying computing systems and how they enable, constrain, shape, and support the creative work that is done on them" (vii). And there is much to be gleaned by inward looking approaches to genre studies, series studies and intermedial analysis that takes into account the ways a game's meaning is frequently transformed and amplified by storytelling that crosses over with other games, series and media.

But while there has been a resurgence of analytical approaches to "the game itself," we are hearing an ever greater call to diversify our understanding of games, game developers and players from scholars 


\section{artnodes}

https://artnodes.uoc.edu

focused on critical race, sexuality and identity studies. Scholarship on these subjects has grown a great deal since early critics began analysing race and gender in terms of in game representation by characters.

The most prominent voices in feminist and queer game studies today, for example, argue that representation is but one dimension of gender and sexuality's impact on gaming, and not necessarily the most important one at that. Shaw's work "extensively critiques the assumption that members of marginalised groups are 'naturally' concerned with representation of a group in which they might be classified and argues that identity, identification, and representation are much more complicated than this model allows" $(2015,22)$ Therefore much research in this vein has moved beyond the analysis of in game representation and examine aspects such as gender dynamics in player communities or the game industry (Fernández-Vara 2014; Consalvo 2008).

Likewise, LGBTQ+ game developers, players and scholars have contributed significantly to the diversification of games and game studies in recent years. As Bonnie Ruberg and Adrienne Shaw explain in their introduction to Queer Game Studies (2017), exploring queerness in games means much more than studying LGBTQ content, players or game creators," and indeed it is possible to "turn to queerness to challenge a variety of dichotomies that have long structured how scholars and designers alike understand games (e.g., narratology/ ludology, production/reception, control/agency, success/failure) (ix-x).

Indeed, this shift away from binary divisions and toward an intersectional point of view is key to understanding the changing role of ludological methodology in game studies.

Race and racism play a prominent role in contemporary video game culture, and an important trajectory of academic analysis is also adding to our understanding of how race affects the gaming experience. Kishonna Gray and David Leonard frame their recent work as a response to the toxicity of \#Gamergate, which "brought the hidden reality of harassment, cyberbullying, sexism, racism, homophobia, transphobia, and other injustices to light" $(2018,21)$, highlighting the need for game studies scholarship that is sensitive to these issues.

Jennifer Malkowski and Treaandrea M. Russworm, for their part, argue that identity is as important as other issues that frequently receive more attention from game studies scholars and publishers, arguing that "[i]t is both possible and essential to study representation productively in video games, even as this pursuit might initially seem poorly aligned with the ontology of video games (built as they are on processes and actions) or with disciplinary trends toward areas like code and platform studies" (2017, 2). In so doing, they defend identitybased cultural critiques of games-those analyses that go beyond "the game itself" - against the purportedly "hardcore" scholarship of those more focused on technical aspects of games and game design.

Postcolonial and decolonial analysis have also contributed importantly to our understanding of games and game culture beyond concerns of software and hardware. In his work on games and postcolonialism, Souvik
Divergent Theoretical Trajectories in Game Studies: A Bibliographical Review

Mukherjee argues that "it is high time that the concerns of the millions of gamers in the so named postcolonial geographies are represented," and that above and beyond discussions of gender, race and religion, "the intrinsically connected questions of the representations of empire and the post-colony need a separate and yet related consideration" (2017, 9). Nick Dyer-Witheford and Greig de Peuter (2009) have also applied Antoni Negri's theoretical paradigms to their work in Games of Empire. Likewise, Penix-Tadsen (2019) has argued that by studying the games and game cultures of underexamined geographical locales in the Global South, we gain a better understanding of the ways video games become intertwined with politics, economics and culture around the world.

Another way of understanding games' meaning "from outside the game" is through digital ethnography, the critical analysis of players, audiences and fans of video games in real-world environments. Pioneering works in digital ethnography have focused on unpacking the roles and impact of communities built around massively multiplayer online (MM0) games (Taylor 2006) and emergent fan cultures in networked digital worlds (Pearce 2009).

Today's gaming audiences no longer consist of players alone, but also spectators, fans, streamers, commentators, modders and prosumers. More and more, engagement with a video game means not only playing it, but manipulating it, remixing it, and leaving one's own unique trace. A growing body of scholarship focuses on aspects of user-generated content (UGC) such as the "convergence" between top-down publication and grassroots cultural production (Jenkins 2006), the creation of "metagames" that transfer game elements into other media or play games in ways their designers never intended (Boluk and Lemieux 2017; Consalvo 2007).

UGC is the norm rather than the exception in many globally successful games, including Minecraft, The Sims, Mario Maker and Second Life. And communities of software modifiers-modders-have given new life to open-world series like Grand Theft Auto, Fallout and The Elder Scrolls. In fact, some of the most successful games in recent years, including Dota 2 and Player Unknown's Battlegrounds started as fan-produced mods of other games. Community participation in game development is another way the meaning of games and game culture escapes the boundaries of a strict, formalist ludology.

Finally, a growing body of scholarship on regional game studies demonstrates the many ways video game development and consumption are impacted by the geopolitical and economic regions in which games circulate. As Bjarke Liboriussen and Paul Martin explain, "regional game studies" is an approach that investigates games and gaming cultures at a range of geocultural scales, identifies connections across and between these scales, highlights and addresses unequal global power relations within gaming culture and within the academic study of games, and enriches the field with new perspectives drawn from regional cultural contexts (2016).

Examples of regional analyses of games and game culture include global overviews of game production and consumption (Huntemann and Aslinger 2013, Wolf 2015) as well as those focused on regions 


\section{artnodes}

https://artnodes.uoc.edu

like Latin America (Penix-Tadsen 2016) and countries such as Japan (Consalvo 2016, Hutchinson 2019), South Korea (Jin 2010) and Soviet era Czechoslovakia (Švelch 2019). In each case, approaching games through the lens of "cultural ludology" (Penix-Tadsen 2016) provides insight into the ways geographical locale and cultural context impact games' meaning and circulation.

In concert, these diversifying trajectories offer a further reminder of the difficulty of fully understanding video games if we constrain ourselves to studying strictly "the game itself," while showing how ludology has responded to the need for diversification and attention to the "human factor" in game analysis.

\section{Conclusion}

This bibliographical review of how contemporary trajectories of game studies research have diverged from initial debates between narratology and ludology brings us to several conclusions. On one hand, a narratological framework has enjoyed sustained currency in contemporary game studies due to its connections with other perspectives including cognitive science and the theory of fictional worlds. Indeed, ludic fictions offer new possibilities for understanding the mechanics of fiction at work in video games, and likewise, the analysis of video games can take on further dimensions and nuances when considered in relation to transmedia narratives and transfictionality.

On the other hand, as can clearly be seen from the diverse ways scholars are redefining the terms of the debates over ludology today, a focus on the unique dynamics of video games as such remains key to understanding many important dimensions of those games' meaning. But at the same time, a restrictive and inwardly-focused analysis of hardware and software alone is insufficient for analysing the full meaning and impact of a game, including the experience of the game for its players.

Unbound by the overly-restrictive terms of a false binary, today's game studies scholars are free to live their best lives as narratologists and ludologists, and so much more. This bibliographical review of the development of game studies demonstrates how diverse voices and interdisciplinary connections have enriched the field's methodologies and approaches, taking it beyond its early debates and into the $21 \mathrm{st}$ century. Today, the theoretical trajectories of game studies continue to evolve in ways that are not only increasingly interdisciplinary, but also profoundly intersectional.

\section{References}

Aarseth, Espen. "Game Studies: How to play -Ten play- tips for the aspiring game-studies scholar". Game Studies. The international Journal of Computer Game Research 19, no. 2 (2019). http:// gamestudies.org/1802/articles/kagen
Divergent Theoretical Trajectories in Game Studies: A Bibliographical Review

Aarseth, Espen. "A narrative theory of games". Proceedings of the International Conference on the Foundations of Digital Games. 129-133 (2012). D0l: https://doi.org/10.1145/2282338.2282365 Aarseth, Espen. "Genre Trouble: Narrativism and the Art of Simulation." In First Person: New Media as Story, Performance, and Game, edited by Noah Wardrip-Fruin and Pat Harrigan. Cambridge, London: MIT Press, 2004.

Bell, Alice. "Interactional Metalepsis and Unnatural Narratology". Narrative 24, no. 3: 294-310 (2016). D0l: https://doi.org/10.1353/ nar.2016.0018

Boluk, Stephanie, and Patrick Lemieux. Metagaming: Playing, Competing, Spectating, Cheating, Trading, Making, and Breaking Videogames. Minneapolis: University of Minnesota Press, 2017. DOI: https://doi.org/10.5749/9781452958354

Calleja, Gordon. In-Game: From Immersion to Incorporation. Cambridge, MA: MIT Press, 2011. D0I: https://doi.org/10.7551/ mitpress/8429.001.0001

Consalvo, Mia. Atari to Zelda: Japan's Videogames in Global Contexts. Cambridge, MA: MIT Press, 2016. D0I: https://doi.org/10.7551/ mitpress/1802.001.0001

Consalvo, Mia. Cheating: Gaining Advantage in Video Games. Cambridge, MA: MIT Press, 2007.

Consalvo, Mia. "Crunched by passion: Women game developers and workplace challenges." In Beyond Barbie and Mortal Kombat: New perspectives on gender and gaming, edited by Yasmin B. Kafai, Carrie Heeter, Jill Denner, and Jennifer Y. Sun, 177-191. Cambridge, London: MIT Press, 2008.

Doležel, Lubomír. Heterocósmica. Ficción y mundos posibles. Madrid: Arco / Libros, 1999.

Doležel, Lubomír. "Porfyry's Tree for the Concept of Fictional Worlds". In Possible Worlds Theory and Contemporary Narratology, edited by Alice Bell y Marie-Laure-Ryan. Lincoln: University of Nebraska Press, 2019. D0I: https://doi.org/10.2307/j.ctv8xng0c.6

Dyer-Witheford, Nick and Greig de Peuter. Games of Empire: Global Capitalism and Video Games. Minneapolis: University of Minnesota Press, 2009.

Fernández-Vara, Clara. "El mundo de ficción como clave en el proceso de adaptación: El caso de Blade Runner, el videojuego". In Juego digital, edited by J. Sánchez-Navarro, A. Planells, V. Navarro, and D. Aranda. Anàlisi. Quaderns de Comunicació i Cultura, 54: 31-43 (2016). http://dx.doi.org/10.7238/a. v0i54.2903

Fernández-Vara, Clara. "La problemática representación de la mujer en los videojuegos y su relación con la industria." Revista de Estudios de Juventud, no.106 (September 2014): 93-108. https:// www.researchgate.net/publication/309035476_La_problematica_representacion_de_la_mujer_en_los_videojuegos_y_su_relacion_con_la_industria

Fludernik, Monika. Towards a Natural Narratology. London: Routledge, 1996. 


\section{artnodes}

https://artnodes.uoc.edu

Frasca, Gonzalo. "Ludologists Love Stories, Too: Notes from a Debate That Never Took Place". Paper presented at Digital Games Research Conference, Utrecht, The Netherlands (2003). http://www. digra.org/digital-library/publications/ludologists-love-stories-toonotes-from-a-debate-that-never-took-place/

Frasca, Gonzalo. "Ludology Meets Narratology: Similitude and Differences Between (Video) Games and Narrative" (1999). Ludology. org.

Galloway, Alexander R. Gaming: Essays on Algorithmic Culture. Minneapolis: University of Minnesota Press, 2006.

Gray, Kishonna, and David J. Leonard. "Introduction: Not a PostRacism and Post-Misogyny Promised Land: Video Games as Instruments of (In)Justice." In Woke Gaming: Digital Challenges to Oppression and Social Justice, edited by Kishona L. Gray, and David J. Leonard. Seattle: University of Washington Press, 2018.

Herman, David. "Scripts, Sequences, and Stories: Elements of a Postclassical Narratology." PMLA/Publications of the Modern Language Association of America 112, no. 5 (1997). D0I: https:// doi.org/10.2307/463482

Huntemann, Nina, and Ben Aslinger. Gaming Globally: Production, Play, and Place. New York: Palgrave Macmillan, 2013. Dol: https://doi. org/10.1057/9781137006332

Hutchinson, Rachael. Japanese Culture Through Videogames. New York: Routledge, 2019. DOI: https://doi.org/10.4324/9780429025006 Jagoda, Patric. "Videogame Criticism and Games in the Twenty-First Century." American Literary History 29, no. 1: 205-218 (2017). DOI: https://doi.org/10.1093/alh/ajw064

Jenkins, Henry. Convergence Culture: Where Old and New Media Collide. New York: New York University Press, 2006.

Jin, Dal Yong. Korea's Online Gaming Empire. Cambridge, MA: MIT Press, 2010. DOI: https://doi.org/10.7551/mitpress/9780262014762.001.0001

Jones, Steven E. The Meaning of Video Games: Gaming and Textual Strategies. New York and London: Routledge, 2008.

Juul, Jesper. Half-Real. Video Games between Real Rules and Fictional Worlds. Cambridge, MA: MIT Press, 2005.

Klastrup, Lisbeth, and Tosca, Susana. "Transmedial worlds - rethinking cyberworld design". Proceedings International Conference on Cyberworlds. IEEE Computer Society, Los Alamitos, California, 409-416 (2004). DOI: https://doi.org/10.1109/CW.2004.67

Koenitz, Hartmut. "What Game Narrative Are We Talking About? An Ontological Mapping of the Foundational Canon of Interactive Narrative Forms." Arts 7, no. 4 (2018). D0I: https://doi.org/10.3390/ arts7040051

Liboriussen, Bjarke and Paul Martin. "Regional Game Studies.” Game Studies 16, no.1 (2017). http://gamestudies.org/1601/articles/ liboriussen.
Divergent Theoretical Trajectories in Game Studies: A Bibliographical Review

Malkowski, Jennifer, and Treaandrea M. Russworm. "Introduction: Identity, Representation and Video Game Studies beyond the Politics of the Image." In Gaming Representation: Race, Gender, and Sexuality in Video Games. Bloomington: Indiana University Press, 2017. D0I: https://doi.org/10.2307/j.ctt2005rgq

Marino, Mark C. "Critical Code Studies." Electronic Book Review (2006). https://electronicbookreview.com/essay/critical-codestudies/

Mäyrä, Frans, and Sotamaa, Olli. Need for Perspective: Introducing the Special Issue "Reflecting and Evaluating Game Studies". Games and Culture 12, no. 6, 495-498 (2017). D0l: https://doi. org/10.1177/1555412016672780

Mäyrä, Frans. "Getting into the Game: Doing Multidisciplinary Game Studies." In The Video Game Theory Reader 2, edited by Bernard Perron and Mark J. P. Wolf. New York: Routledge, 2009.

Montfort, Nick. "Continuous Paper: The Early Materiality and Workings of Electronic Literature." Modern Language Association, Philadelphia, PA, 2004. DOI: http://nickm.com/writing/essays/ continuous_paper_mla.html

Mukherjee, Souvik. Videogames and Postcolonialism: Empire Plays Back. Palgrave Macmillan, 2017. D0l: https://doi.org/10.1007/9783-319-54822-7

Pearce, Celia. Communities of Play: Emergent Cultures in Multiplayer Games and Virtual Worlds. Cambridge, MA: MIT Press, 2009. DOI: https://doi.org/10.7551/mitpress/8039.001.0001

Penix-Tadsen, Phillip. Cultural Code. Video Games and Latin America. Cambridge, MA: MIT Press, 2016. D0I: https://doi.org/10.7551/ mitpress/10350.001.0001

Penix-Tadsen, Phillip. "Introduction: Video Games and the Global South." In Video Games and the Global South, edited by Phillip Penix-Tadsen. Pittsburgh, PA: ETC Press, 2019.

Planells, Antonio. Videojuegos y mundos de ficción. De Super Mario a Portal. Madrid: Cátedra, 2017.

Ryan, Marie-Laure. "From Possible Worlds to Storyworlds: On the Worldness of Narrative Representation". In Possible Worlds Theory and Contemporary Narratology, edited by Alice Bell, and MarieLaure-Ryan, 62-87. Lincoln: University of Nebraska Press, 2019. D0I: https://doi.org/10.2307/j.ctv8xng0c.7

Ryan, Marie-Laure. "Transmedia narratology and transmedia storytelling”. Artnodes, no. 18 (2016). Dol: https://doi.org/10.7238/a. v0i18.3049

Sicart, Miguel. Play Matters. Cambridge, MA: MIT Press, 2013. DOI: https://doi.org/10.7551/mitpress/10042.001.0001

Taylor, T. L. Play Between Worlds: Exploring Online Game Culture. Cambridge, MA: MIT Press, 2006. D0I: https://doi.org/10.7551/ mitpress/5418.001.0001 


\section{artnodes}

https://artnodes.uoc.edu

Divergent Theoretical Trajectories in Game Studies: A Bibliographical Review

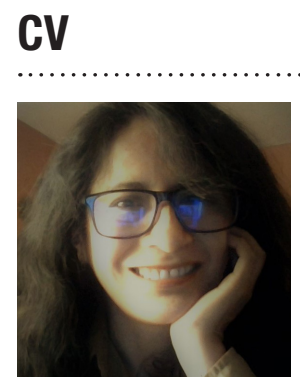

Rosa Núñez-Pacheco

Universidad Nacional de San Agustín de Arequipa

rnunezp@unsa.edu.pe

Rosa Núñez-Pacheco is Professor of Creative Writing and Literary Theory at the Department of Literature and Linguistics, National University of Saint Augustine of Arequipa (UNSA), Peru. Doctorate in Social Science and Master in Discourse Analysis from UNSA. Currently, she is finishing a PhD in Communication at the Inter-University Programme of Seville, Huelva, Malaga and Cadiz. Her research interests include Comparative Literature, Latin-American Essay and Game Studies. She has also written national and international publications on literature, cultural studies, and education. She has participated in the project "Transmedia Storytellings, Video Games, and Literature", and she is currently principal investigator of the project "Trasmedia Gamification and Video Games to improve writing in higher education".

ORCID: http://orcid.org/0000-0002-4576-6224

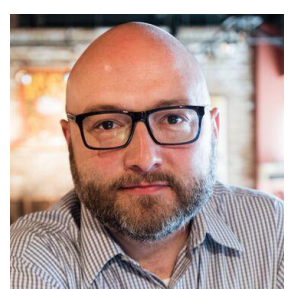

\section{Phillip Penix-Tadsen}

University of Delaware

ptpt@udel.edu

Phillip Penix-Tadsen is a specialist in contemporary Latin American cultural studies and regional game studies, focusing on the intersections between politics, economics, digital media and visual culture throughout Latin America today. He earned a PhD from Columbia University and is Associate Professor of Spanish and Latin American Studies at the University of Delaware, where he regularly teaches courses on Latin American cultural studies and game studies. Prof. Penix-Tadsen is the author of Cultural Code: Video Games and Latin America (MIT Press, 2016) and editor of the anthology Video Games and the Global South (ETC Press, 2019). 